\title{
Kemampuan Spatial Thinking Guru Geografi Madrasah Aliyah Sulawesi Utara
}

\author{
Joyce Ch. Kumaat ${ }^{1}$, Cahyadi Nugroho ${ }^{2}$, Nismawati ${ }^{3}$, Aghata A. Tumengkol ${ }^{4}$ \\ ${ }^{1,4}$ Program Studi Geografi, Fakultas Ilmu Sosial, Universitas Negeri Manado \\ ${ }^{2}$ Jurusan Pendidikan Geografi, Fakultas Ilmu Sosial, Universitas Negeri Manado \\ ${ }^{3}$ Program Studi Pendidikan Sosiologi, Fakultas Ilmu Sosial, Universitas Negeri Manado \\ e-mail: joykekumaat@unima.ac.id
}

\begin{abstract}
Spatial thinking is needed by a teacher in providing understanding to students for better knowledge transfer. This research was based on the background of the geography teacher at Madrasah Aliyah (MA) North Sulawesi, who was not a geography teacher. Analysis of spatial thinking capabilities is carried out using software, namely Google Earth with material on maps, Geographic Information Systems and Remote Sensing which are summarized into a complex series of activities in the Substantial Technical Training activities. The results showed that the ability of spatial thinking which is still experiencing problems is in the aspects of mastery of data preparation and data interpretation. It is necessary to strengthen skills to sharpen the spatial thinking of a teacher through exercises and other training activities as well as integration between universities and the Geography MGMP in North Sulawesi to hold periodic activities to reach teachers who are not in their field to teach geography subjects in the learning process.
\end{abstract}

Keywords: Spatial thinking, Geographic Information System, Education, Teacher Competence

\begin{abstract}
Abstrak: Kemampuan berpikir spasial (spatial thinking) sangat diperlukan seorang guru dalam memberikan pemahaman kepada peserta didik guna transfer knowledge yang lebih baik. Penelitian ini didasari latar belakang guru geografi Madrasah Aliyah (MA) Sulawesi Utara yang bukan berasal dari rumpun ilmu geografi. Analisis kemampuan spatial thinking dilakukan dengan menggunakan perangkat lunak yaitu Google Earth dengan materi bahasan peta, Sistem Informasi Geografi dan Penginderaan Jauh yang dirangkum menjadi satu rangkaian kegiatan yang kompleks dalam kegiatan Diklat Teknis Substansial. Hasil penelitian menunjukkan bahwa kemampuan spatial thinking yang masih mengalami kendala berada pada aspek penguasaan penyusunan data dan interpretasi data. Perlu dilakukan pemantapan keterampilan untuk menajamkan spatial thinking seorang guru melalui latihan-latihan maupun kegiatan pelatihan lainnya serta integrasi antara pihak perguruan tinggi dengan MGMP Geografi di Sulawesi Utara untuk mengadakan kegiatan periodik guna menjangkau guru-guru yang bukan bidangnya untuk mengajar mata pelajaran geografi didalam proses pembelajaran.
\end{abstract}

Kata Kunci: Spatial thinking, Sistem Informasi Geografi, Pendidikan, Kompetensi Guru

\section{PENDAHULUAN}

Setiap orang memiliki kemampuan dalam menganalisa kondisi lingkungan sekitar. Beberapa orang secara alamiah mampu beradaptasi dengan lingkungannya dengan baik. Bagi seorang guru geografi kemampuan dalam menganalisa lingkungannya sangat diperlukan. Konsep-konsep seseorang yang mampu dalam menganalisa lingkungannya berkaitan dengan spatial thinking atau biasa disebut kemampuan berpikir spasial. Kemampuan spatial thinking seseorang diilustrasikan sebagai seseorang yang mampu membaca kondisi sekitar melalui suatu data baik itu data primer ataupun sekunder. Mereka mampu merencanakan, memahami dan menerapkan sesuatu hal yang dilakukan dengan baik. Orang yang mempunyai kecerdasan spasial memiliki ciri khusus. Ciri khusus dari kecerdasan spasial adalah memahami arah, melakukan proses berpikir, dan menggunakan tiga dimensi untuk merancang sesuatu (Badan Informasi Geospasial, 2015).

Kemampuan berpikir spasial (spatial thinking) sangat diperlukan seorang guru dalam memberikan pemahaman kepada peserta didik guna transfer knowledge yang lebih baik. 